\title{
Avaliação do perfil metabólico produzido pela linhagem Streptomyces wadayamensis A23
}

\author{
Luciana G. de Oliveira (PQ), Ana B. Goncalves (IC).
}

\section{Resumo}

O estudo do genoma de diversas linhagens de Streptomyces revelou uma grande abundância de clusters de genes que codificam metabólitos secundários muitos dos quais apresentam atividade biológica. ${ }^{1}$ Neste trabalho foram realizadas análises de espectros de massa de cultivos da linhagem Streptomyces wadayamesis A23 que confirmaram a produção de diversos metabólitos como desferrioxaminas B e E, antimicinas, manopeptimicina, aerobactina e outros inéditos. Uma segunda etapa visava à busca guiada de moléculas alvo com experimentos de aproximação genomisotópica através da adição de substratos marcados isotopicamente e que são inseridos na estrutura molecular durante a biossíntese. ${ }^{2}$

Palavras Chave: aproximação genomisotópica, Streptomyces, metabólitos.

\section{Introdução}

Micro-organismos do gênero Streptomyces são conhecidos por produzir uma grande diversidade de metabólitos secundários. Muito destes metabólitos ainda não tem função atribuída pelo que seu papel no organismo não está completamente elucidado. ${ }^{3}$ Dentre esta variedade de metabólitos destacam os policetídeos e peptídeos não-ribossomais por constituir um grupo de moléculas que podem apresentar atividades antimicrobianas, antifúngica, antiparasitária e antitumoral entre outras. ${ }^{4}$

Este trabalho descreve a avaliação do perfil metabólito da bactéria Streptomyces wadayamensis com ênfase na descoberta de novos policetídeos, terpenóides e peptídeos nãoribossomais.

\section{Resultados e Discussão}

A linhagem Streptomyces wadayamensis A23 foi cultivada em diferentes meios de cultura. A fermentação foi realizada por 7 dias a $30{ }^{\circ} \mathrm{C}$. Ao completar este tempo, foi realizada uma extração com acetato de etila e os extratos obtidos foram tratados com metanol e analisados por UPLC-MS (modo positivo). Os perfis cromatográficos da maior parte das amostras revelou a presença de espécies químicas similares.

Com as informações geradas pelas análises UPLC-MS foi realizada uma busca de possíveis alvos já relatados na literatura, com o auxilio da base de dados Dictionary of Natural Products. ${ }^{5}$

A partir da combinação dos dados, encontraramse diversos metabólitos já conhecidos, tais como desferrioxaminas B e E (m/z 562 e 601), antimicinas A1, A4, A7 e A8 ( $\mathrm{m} / \mathrm{z} 547,505,519$ e 533), manopeptimicina $(\mathrm{m} / \mathrm{z} 1294)$, aerobactina
( $m / z$ 564) e enterobactina $(m / z$ 669), além de moléculas cujas estruturas são desconhecidas, como $\mathrm{m} / \mathrm{z} 914$ e 639 . A presença das antimicinas e desferroxaminas confirmou a previsão realizada na análise do genoma de $S$. wadayamensis A23 que mostrava a presença dos clusters que codificam para estes metabólitos.

Posteriormente realizou-se a adição de ${ }^{15} \mathrm{~N}$ fenilalanina em todos os meios de cultivo. Um dos meios (GYM) apresentou um perfil interessante de incorporação do substrato. Então se realizou a adição de D-glicose- ${ }^{13} \mathrm{C}_{6}$ e diversos aminoácidos marcados $\operatorname{com}{ }^{15} \mathrm{~N}$ a este meio. Os espectros obtidos estão sendo estudados.

Reações de PCR foram realizadas e observou-se que o gene de interesse possui 2000 pb. A próxima etapa envolve a triagem de colônias de E. coli onde o DNA recombinante proveniente da Streptomyces será inserido.

\section{Conclusões}

A avaliação da linhagem Streptomyces wadayamensis A23 permitiu a identificação de várias moléculas, algumas já descritas na literatura e outras inéditas, o que evidencia a grande capacidade da linhagem em biossintetizar outras moléculas.

\section{Agradecimentos}

IQ - UNICAMP

${ }^{1}$ De Oliveira, L. G.; Pupo, M. T.; Vieira, P. C. Quim. Nova, 2013, 36, 1577-1586

${ }^{2}$ Gross, H.; Stockwell, O. V.; Henkels, D. M.; Nowak-

Thompson, B.; Loper, E. J.; Gerwick H. W. Chemistry \&

Biology, 2007, 14, 53-63

${ }^{3}$ Dewick, P.M. Medical Natural Products, John Wiley \& Sons, Ltd, UK, 2002

${ }^{4}$ Rev. bras. plantas med. vol.15 no.4 supl.1 Botucatu 2013

${ }^{5}$ http://dnp.chemnetbase.com/ 